\title{
Ideology Contestation in Management of University Library Development
}

\author{
Nurdin Laugu* \\ Faculty of Adab, Universitas Islam Negeri Sunan Kalijaga, Yogyakarta - Indonesia
}

\begin{abstract}
Library collection development is mostly studied as professionalism based on a positivistic paradigm neglecting constructivist-based paradigm. This constructivist base is reflected in various factors, such as ideology and commodification, which influence collection development. This research aims to investigate ideological contestation and commodification of institutions and audiences related to the collection development of Muhammadiyah University library. The ideological contestation was examined using Giddens' structuration and Bourdieu's habitus. The research data was collected from interviews with five informants from librarians and library directors. The data were supported by observation and documentation. The data obtained were analyzed using the Miles and Huberman technique based on three stages: reduction, display, and conclusion/verification. The results of the research found three formations in contestation, i.e. internal institutions, external institutions, and professionalism of librarians. The internal institution represented by the UMY Library encountered with outside institutions, such as American Corner, Iranian Corner, and publishers. Meanwhile, librarians show their professionalism in facing the ideological domination of those institutions through various strategies regarding the development of library collection.
\end{abstract}

Pengembangan koleksi perpustakaan cenderung dikaji sebagai profesionalisme berbasis paradigma positivistik semata, sehingga melupakan akar paradigma konstruktivistiknya. Bentuk konstruktivistik ini tergambar pada keragaman faktor, seperti ideologi dan komodifikasi, yang memengaruhi pengembangan koleksi. Penelitian ini berupaya menemukan kontestasi ideologi dan komodifikasi lembaga dan khalayak berkenaan pengembangan koleksi perpustakaan UMY (Universitas Muhammadiyah Yogyakarta). Kontestasi ideologi tersebut dikaji menggunakan konsep strukturasi Giddens dan habitus Bourdieu. Data penelitian ini dikumpulkan dari wawancara bersama lima orang informan dari pustakawan dan kepala perpustakaan. Data tersebut didukung pengamatan langsung dan dokumentasi. Data yang diperoleh dianalisis menggunakan teknik analisis Miles dan Huberman melalui tiga tahap, yaitu reduksi, display, dan simpulan/verifikasi data. Hasil penelitian ditemukan tiga formasi dalam proses kontestasi, yaitu institusi internal, institusi eksternal, dan profesionalitas pustakawan. Institusi internal diwakili perpustakaan UMY berhadapan dengan institusi-institusi luar, seperti American Corner, Iranian Corner, dan penerbit. Sementara, pustakawan menunjukkan profesionalitasnya dalam menghadapi dominasi ideologis kedua jenis lembaga tersebut melalui berbagai strategi berkenaan dengan pengembangan koleksi perpustakaan.

Keywords: ideology; contestation; collection development; commodification; Muhammadiyah

*Corresponding Author: Nurdin Laugu (nurdin@uin-suka.ac.id). Faculty of Adab, Universitas Islam Negeri Sunan Kalijaga, Jl. Laksda Adisucipto, Depok, Sleman, Daerah Istimewa Yogyakarta 55281. 


\section{Introduction}

Collection development of libraries among librarians is one of the professional tasks. Librarians consider that all types of collections owned by libraries should be managed through professional considerations, based on user needs, impartiality, and open to all gender, thought, race, religion, and the like (Evans 2000; Johnson 2018; Lappegård, Bernhardt, and Goldscheider 2017). This idea is in line with the understanding that libraries as information preservation institutions are required to accommodate all types of information so that it is well channeled, accessible to all parties and all parties can access all types of information (IFLA 2019; Vidal and Huinink 2019; Zerek 2014). This understanding seems very positivistic and ignores social aspects and their construction in potentially constructive community interactions. Not all phenomena occur because of natural or causal processes. Some happen because of ideological effects that are to name them as constructivist phenomena. For instance, some items of the collection acquired maybe not based on the library users' needs, but they are from the ideological considerations, commodifications, and other interests (Leckie, Given, and Buschman 2010; Malagueño et al. 2019; Smith et al. 2017). Due to this reason, the researcher is driven to investigate other sides behind the linear events that have been known as definite and continuous.

This constructivist phenomenon can be seen in various libraries, especially in UMY Library. Therefore, a research approach, which is constructivist paradigm, is important to use to see holistically the variation of library phenomena.
The importance of this non-positivistic approach is not only because it can uncover the events of social empiricism, but also more critical to understand the problems of libraries based on multiperspective (Denzin and Lincoln 1997; Leckie and Buschman 2009; Leckie et al. 2010). Through this approach, the research found many issues, including, about the existence of ideological contestation in the development of UMY Library collections as well as their commodification links in gaining added value for contestants' ideologies. At this point, ideological contestation can be seen in three formations, which include internal institutions, external institutions, and professionalization of librarians, that all of these encounter one another in a mutual face in influencing the process of UMY Library collection development.

To read such issues above, the critical social theory of Giddens (1984) and the social practice of habitus from Bourdieu (1986, 1991, 1998) have become important in understanding the ideological contestation of the collection development. The structuration of Giddens helps understand how dialectics between structures and agencies face each other in developing the collection of UMY Library. Meanwhile, habitus of Bourdieu helps explain how the social practices occur dynamically, which are supported by a variety of capital and rules so that both structures and actors influence each other in creating a habitus. It means that the habitus of person(s) is formed through a process of disposition or in the form of a historical product that results in the practice of individual behavior or a collective one. Habitus of a person that has been formed is no 
other than the existence of a relationship between the actor himself and the social conditions that surround him. The ideological contestation is not only framed in the three formations above but also creates implications for the commodification of institutions and audiences (Laugu 2015; Mosco 1996; Yu 2019).

Eagleton (2006) stated that ideology has a diverse understanding that cannot be put together because the formulation of the ideology is not all relevant to one another. Among these ideological formulations are those that are pejorative, while others are not. In line with the inherent question, some are epistemological and others are not. As a result of its dynamics, it has the potential to become a tool for legitimizing interests. Stuart Hall in Storey (1993) proposed five definitions. First, ideology refers to a collection of ideas articulated by certain groups, such as the ideology of political parties and professional groups. Second, ideology is considered a distorted mask. Ideology is used to see how text and cultural practices present images of distorted reality and false consciousness. The third definition refers to a particular world image that depends on community ideas that are more conflictual than consensus. Fourth, ideology is not a simple set of ideas, but rather as a material practice of everyday life that includes certain rituals and customs, which have a binding influence on social order. Finally, ideology operates at the level of connotation, which is, by Rokand Barthes (1981) referred to as a myth that refers to the struggle of hegemony to limit connotations, determine certain connotations, and produce new connotations.
Ideology is also understood as a discourse, which is bound by certain social interests that cannot be free from a problem. This refers to the intended situation that the social interests are related to the contents that produce a power relation, not the interests that arise from the natural elements of the human body, such as eating, communicating with each other, understanding, and monitoring the environment (Eagleton 2006). For this point, a statement becomes ideological if it is claimed that the statement is reinforced by an ulterior motive that is closely related to the legitimacy of certain interests in a struggle for power. The statement of someone who is empirically correct and does not carry a hidden message is a piece of language, not as a piece of discourse. In addition to the discourse, if a rhetorical action aimed at producing a certain effect, then the statement also entered as an ideological or false consciousness. This happens for two reasons, first; statements include a kind of fraud, for example, a spokesperson does not state what is intended, and second, the statement contains a certain implication (Eagleton 2006; Margulies 2018).

Culture is a complex term because it is used by some different disciplines in different thinking frameworks (Sutrisno and Putranto 2005). The complexity is also because this term does not represent an entity in the world of independent objects, but rather as a marker that is always changing and allows to be understood differently by those who discuss different human activities for different purposes. The concept of culture, thus, becomes a useful tool for those who want to do something different when the use and 
meaning of life keep changing (Barker 2004, 2005). At this point, the library may be and even become one of the objects of the application of that understanding. This kind of cultural concept is defined by many social scientists. Raymond Williams (1987), for example, defined culture in three meanings. First, culture is understood as a general process of intellectual, spiritual, and aesthetic development. This process gave birth to great people, such as philosophers, scientists, and poets. Second, culture is understood as a special way of life, whether it is related to a person or group at a certain period. Culture in this form is the development of literacy, holiday, sport, and religious ceremony. Finally, culture is understood as a form of work and practice in the form of intellectual activities, especially artistic (Abdullah 2009; Kroeber and Kluckhohn 1952; Storey 1993).

The various meanings above indicate that a cultural term is a complex concept. It has different meanings by different people, depending on the purpose and who understands the term. In this context, culture tends to be a political term and play behind power. Barker (2005) stated culture as a political language because it is an expression of the social relations of class power that seeks to naturalize the social order as an unavoidable fact on the one hand, but obscure exploitative relations on the other. According to him, such a culture is nothing but ideological. The red line that connects the library and culture can be seen from the views or concepts above. For them, culture is a concept that is open to all understandings that are specifically loaded with ideological and political contents. Therefore, libraries as cultural products are important to read in the guide to cultural concepts so that researchers' understanding is structured in the context of discursive practices of libraries as an active and potential cultural process of political and ideological issues. It is important to dismantle the paradigmatic crisis of the study of libraries that are stuck stagnant on mere technical and managerial phenomena towards cultural reproduction to get a more critical approach (Buschman 2003; Laugu 2015).

The previous research of the qualification of library leader showed that the leadership in the University of Muhammadiyah Yogyakarta is based on Muhammadiyah ideology, while the leadership model is a democracy (Yusniah 2019). Ideological contestation means historical and paradoxical spaces. The historical space is defined that library development is caused by the development of information technology and the management of the library. The second space is related to the use of different spaces affect different regulation (Fatmawati, Udasmoro, and Noviani 2017). Another research focused on library education in twentieth-century America. The finding showed that there was shifting ideology in managing book collection in the library from humanities to social science ideology including gender, race, and class for library management (Pawley 2017). This research aims to investigate ideological contestation and commodification of institutions and audiences related to the collection development of Muhammadiyah University library. There are three formations in contestation in this institution that will be explained in this paper, they are an internal institution, external institutions, and profes- 
sionalism of librarians. I argue that there is strong ideological interaction between structure and agency. The structure is played by institutional elements namely UMY Library whereas actors are played by critical and professional librarians.

This research is carried out qualitatively with constructivist paradigms as well as critically interpretive to see something that is happening behind the technical-managerial phenomena of libraries (Laugu 2015). The research also departed from a question toward the status quo of professionalism, which was echoed by the mainstream library approach assuming the library work process based solely on the world of professionalism. To achieve the results based on this paradigm, research data is obtained through three main techniques, namely in-depth interviews, direct observation, and archive documentation. Interviews will be a leading source that is reinforced by the other two techniques so that the discussion of interview sources is more prominent than the other two. The data were analyzed using Miles and Huberman in three steps, i.e. reduction, display, and conclusion/verification (Denzin and Lincoln 1997; Sugiono 2006).
The informants used are five persons; from the library leader to those who are librarians believed to be able to provide accurate information related to the research. The selection of these informants is purposive because the researcher has often researched this place, where the researcher feels that he already knows much about the library from bottom to up-level management that becomes like the object of the research. The description of the informants is provided in the table below.

\section{Library collection as ideological and political artifacts}

The library collection is a collection of materials that contain various kinds of information for various purposes, both scientific and nonscientific, such as technology and entertainment (see KBBI). The collection is also understood as a publication consisting of various works (Wordweb Thesaurus/Dictionary). The works are the products of people that are produced from various efforts and interests. Thus, the collection is a collection of ideas that involve a collection of perspectives, thoughts, and personal ambitions or public interests. Collections in libraries are managed through a section often referred to as a

Table 1

Background of informants

\begin{tabular}{lllll}
\hline No & Pseudonym & Education & Gender & Age/Length of working \\
\hline 1 & LAHS & Master Degree & Male & $72 / 7$ years \\
2 & ARPW & Master Degree & Female & $28 / 5$ years \\
3 & SAFD & Bachelor Degree & Male & $51 / 21$ years \\
4 & SUSB & Bachelor Degree & Male & $55 / 21$ years \\
5 & LANT & Undergraduate Degree & Female & $44 / 18$ years \\
\hline
\end{tabular}

Source: Interview with informants, 26/06/2019 
a collection development division. Evans (2000) said that collection development is a process of building library materials to meet the information needs of users in a timely and economical manner through locally owned information sources or from other organizations. Whereas, IFLA states that the development of collections is a focus on issues of methodology and topics relating to the procurement of printed library materials or other analogs through purchases, exchanges, gifts, legal deposits, licenses, and purchases of electronic information sources (IFLA 2019).

The definition of collection and publication process above illustrates dynamic conditions not indefinite - and even ups and downs of interests, which underlie the establishment of an agreement for the birth of works. This indicates that works are not born without negotiation, both internally and externally. Furthermore, collections are present in the middle of the task of collection development that is also not automatic, but the product of this task is also influenced by various interests, i.e. ideological, political, and including professionalism (Bourdieu 1986, 1991, 1998). Individuals involved in the development team are not uniform. Education, culture, wisdom, and even ideology and politics are all not going together because they depart from different backgrounds. Based on this fact, the presence of a library is full of dynamics whose construction consists of building elements of culture, especially the reason that is inherent in each actor (Barker 2005). At this point, the collection as the production of culture becomes ideological and political artifacts (Althusser 2014; Margolis and Laurence 2007), which can be a foothold in developing library management, especially at UMY Library.

\section{Contested ideologies in the collection development of libraries.}

The collection development is a part of several people who work on the name of something determined by several people who are also different in several thoughts, ideas, and even ideologies or political directions. The differences that surround the realm of social practices institutional communal and interests - live in a social interaction formed in a habitus or structuration. Habitus in Bourdieu's view (Grenfell 2010) is regarded as a structure that is "structured" and that is "structuring". The structure is structured by the past and present environment, while structuring is that one's habitus helps shape current and future practices. It is called as a structure because it is systematically arranged, not randomly or without patterns. This structure includes a system of dispositions that results in perception, appreciation, and practice. Habitus serves as the dialectical basis between structure and agency, which aims to understand a society through the dismantling of the disguised power relations between those structures and agencies (Harker, Mahar, and Wilkes 2005).

Meanwhile, Giddens (1984) proposed another concept, but the main idea is in line, namely the effort to overcome the problems of the dichotomy between structure and agency. He considered that structural-functional concepts are trapped in a naturalistic view that reduces the role of actors in a structure, which ultimately history is viewed mechanically, not a contingency product of agency activity. He also did not agree with 
phenomenological constructionism by which he assumed it has fallen on subject imperialism. He sought to reconcile the two terms through the concept of structuration, which tries to equalize the role of structure and agency in the process of the reproduction of the social system. So, every social action occurs through a process of contestation between structures and agencies, as well as habitus in influencing social practices that occur in social interactions (Bourdieu 1986, 1990, 1998). Both of these concepts are interesting seen in the frame of the contestation in the collection development of UMY Library.

\section{Collection Development of Muhammadiyah University Library}

The library of UMY (Muhammadiyah University Yogyakarta) is one of the technical implementing units that support the achievement of UMY's vision and mission as an educational and knowledge institution for society, especially the Islamic community. As a supporter of the institution's vision and mission, UMY Library has a strategic position to involve in transforming the university's vision and mission. Its strategic position lies in the selection of collections that can be reflected in whether the procurement of collections is based on knowledge needs or the ideological supervision needs toward the academic community. These two choices will be seen as a process of contestation involving the ideology of institutional actors. However, before further entering the discourse, this paper will show a glimpse of the management of collections owned by the UMY Library in general.

In the beginning, UMY Library with a very limited collection was established on August 1,
1982, and located on Jalan KH. Ahmad Dahlan No. 4 Yogyakarta. Two years later, 1984, the library was moved to the Wirobrajan area, which is now the 7th Muhammadiyah Senior High School of Yogyakarta. In 1997 the library was moved to a new campus on Jalan HOS. Cokroaminoto No. 17 Yogyakarta. Along with the development of UMY, the Integrated Campus of UMY was built in 1995 on the South Ring Road, Tamantirto, Kasihan Bantul. After several buildings were completed in July 1998, the library was moved and placed in one of the rooms on the 1st floor of the KH. AR. Fakhruddin Building at the Integrated Campus to serve non-exact science students. Two years later, precisely since July 19, 2000, UMY Library officially occupied a new building on the 3rd floor of the KH. Mas Mansur Building (Building D) until now.

UMY Library in carrying out its activities and programs is based on its vision and mission. The vision of the library is "excellent in information services in the fields of knowledge, Islam, and Muhammadiyahism based on information technology." To achieve this vision, UMY Library has a mission of gathering, managing, and storing academic works in general and UMY academicians' scientific works in particular. Besides, empowering sources of information, science, Islam, and Muhammadiyahism is carried out. Organizing knowledge sharing, such as book reviews and discussions encourages the dissemination of knowledge or collections to the academicians. The final mission is to improve the quality of human resources by involving them in formal and non-formal education.

UMY Library Building that occupies KH. Mas Mansur Building, also called Building D, consists 
of five floors even though until now only two floors have been used for library spaces, namely floor 2 and 3 with an area of $1,970 \mathrm{~m}^{2}$. The second floor is used for two corner services, namely American and BI Corners, which were before 2014 found Iranian Corner, and institutional repository room, which contains a collection of student final assignments in the form of bachelor theses, master theses, and lecturers' research reports, serial space consisting of newspapers, journals, and magazines, discussion rooms, free brochure and magazine display rooms, photocopying rooms, and french food stalls (library cafes). Meanwhile, the third floor is used for head and administration rooms, library material processing rooms, circulation rooms for library book collections, and Muhammadiyah Corner. Meanwhile, the other three floors, namely the $G$ (Ground) floor, and the first floor are still used for students' classrooms, while the fourth floor is used as UMY Language Center. The collection of UMY Library can be seen in Table 2.

\section{An Analysis of Ideological Contestation in Developing Collection at the Library of UMY}

Political economy and ideology are important discourses that have the potential to create dominance and subordination in the issue of developing collections in the library. This discourse produces contestations between library management actors and other stakeholders, both internally and externally, in building library collections. The dominance and subordination emerge as an impact of political economy and library ideology discourses that further influence the ownership of library collections, both printed and electronic. Ownership of this collection becomes an arena of encounters between actors because of differences in ideology and access to an arena of contestation. Publishers, capital owners, and ideological groups are actors who enliven the discourse of collection development. This discourse is in line with Leckie et al. (2010) who said that world views influence how a person approaches information, both in the form of books, databases, and cultural artifacts, and about how someone as a professional presents information to the public.

The presence of libraries in this context has become important for economic and ideological discourses. The library as an information circulation institution serves as a vehicle for interaction between various actors and social practices that open opportunities for them to play their

Table 2.

Overview of UMY Library collection

\begin{tabular}{lllll}
\hline No & Topic of collection & Number of titles & Number of copies & Other information \\
\hline 1 & General knowledge & 46.809 & 166.994 & Books \\
2 & Islam & 1.881 & 2.481 & Books \\
3 & Muhammadiyah & 1.615 & 2.523 & Muhammadiyah corner \\
4 & Serial & 388 & 5.990 & Printed \& Digital \\
5 & Others & 392 & 513 & Proceedings \\
Source: Library document of UMY, 2019 & & \\
\hline
\end{tabular}


respective interests. Games of interest occur in various ways, especially in ideology and efforts to spread it based on the ideology of each actor. The dissemination of ideology is carried out in the frame of collection building governance, which includes two levels, namely discourse, and practice. The level of discourse works on pushing public opinion to influence users through the complete collection provided by the library, while the level of practice is intended as an effort to influence library users through interaction between library managers or between managers and users.

Through the process of the two levels above, the development of UMY Library collection shows two forms of social interaction, namely the practice of commodification through the political economy and the formation of ideology, which work to maintain institutional vision. The practice of political economy is carried out to obtain collections following the interests of the organization. Collaboration with various parties, especially publishers following the organizational statement, has been developed in various ways.
The process of collection development in the library can be generally described in Figure 1 .

The figure generally describes four main components that mutually construct the circle of ideological contestation in developing collections at UMY Library. These components play important roles that determine the policy of the library in terms of implementing the library vision and mission. Therefore, a library needs to recognize them to build powerful and sustainable programs in the future. Concerning this figure, some interviews have shown such an approach in looking at libraries. Among them, an informant, LAHS, supported by other informants stated concerning ideological issues to see a library as in follow.

"... we have various ways, or may even be as an approach to having collections needed by our users ... maybe that approach is considered unfair [unprofessional] because it closes the possibility of accessing certain collections, such as Shiite books, or at least limit access to these books, as when the leadership of UMY in 2013 instructed to close the Iranian Corner at that time at UMY. After all, it was considered a cult in Islam ...

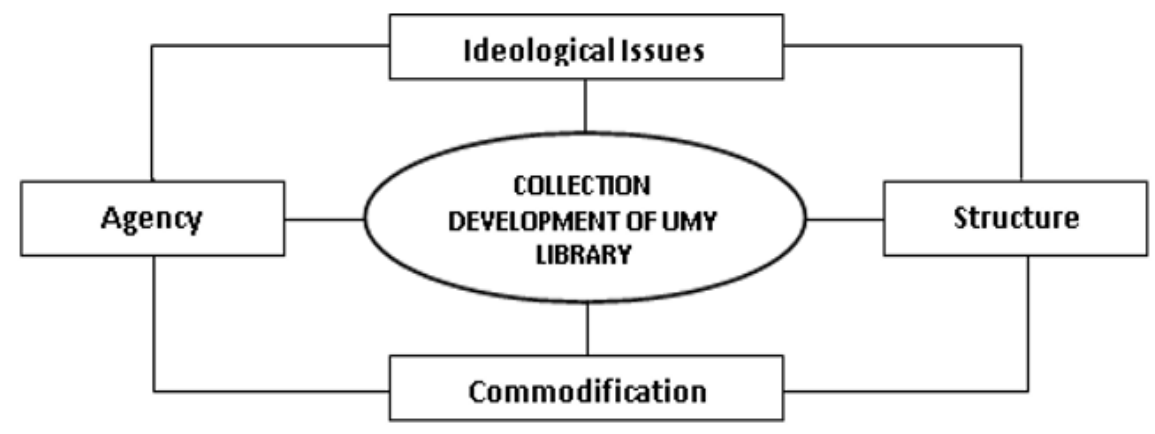

Figure 1.

Collection development in ideological contestation 
some of the Corner books are returned to the Iranian embassy and some are displayed on shelves following other Islamic subjects ... (Interview conducted on June 26, 2019)"

The results of this interview indicate that there is an effort by UMY Library to limit collections that affiliate with other groups that are considered different from the ideological line of their parent institution, Muhammadiyah University. For example, the dissolution of the Iranian Corner has emphasized a real ideological contestation in library management, particularly in developing a collection of UMY Library. The results of this interview illustrate many situations, i.e. among them, why the prohibited Corner was accepted at UMY Library and the other time further it is claimed as an institution that has misguiding teaching, and how the library policy towards developing the library. The presence of the Iranian Corner was initially driven by innovation and creativity among librarians who wanted to optimize the existence of libraries without consideration about ideology as one of the conditions for conducting a collection development. Librarians realize that libraries need a lot of collections to meet their user needs on the one hand. Meanwhile, the library budget, on the other hand, is not enough to meet all their expectations. Thus, collaboration with other institutions is considered as a strategic step to optimize the performance of library collection, especially at UMY Library.

The innovation and creativity of librarians had been reflected in the establishment of the Iranian Corner. They were not influenced by the flow of ideology. They thought that the existence of a maximum collection in a library is more impor- tant than ideological debate. The spirit of innovation gave birth to very open collections or sources of information. However, this situation did not go according to their expectations. The presence of this Corner led to an aroused debate because the Shiite sect as a core ideology of the Corner among the majority of Muhammadiyah actors was considered as a cult. Its presence in the Muhammadiyah education environment is feared to have an impact on the ideology of Ahlussunnah Muhammadiyah. As a result, in 2013 the collaboration regarding the Corner through the Iranian embassy in Jakarta was stopped. Some of the collections were returned to the Iranian embassy and some were included in UMY Library collection shelves. This ideological contestation was clearly illustrated through a Corner dissolution process, which was caused by differences in the religious understandings of both parties (Laugu 2015).

Meanwhile, the policy of developing UMY Library collection is based on Muhammadiyah's religious understandings and based on the scientific fields developed, as the results of interviews with the following informants.

"... the collection development carried out at UMY Library was based on Muhammadiyah's educational development policy, if the general collection was based on the scientific fields developed by UMY ... whereas related to religion would be adjusted to the religious vision carried out by Muhammadiyah, even though we are librarians, we must think openly regardless of the type or form of religious thought in the collection. However, because our parent institution has its vision that might have a rather fundamental difference with the religious vision of other groups so we take a handle based on 
the vision of the organization ... (Interview with LANT, June 26, 2019)"

This interview is reinforced by other informants, such as LAHS and ARPW, who state that UMY Library policy could not be separated from the vision of Muhammadiyah University. The religious vision of Muhammadiyah education is the mainstream vision of Islam in Indonesia, namely Ahlus Sunnah wal Jama'ah, which adheres to the Qur'an and Sunnah of the Prophet Muhammad with a distinctive character as a reformer institution (Asyari 2009; Mulkhan 2010). The clarity of this vision provides a handle for the library to serve as the basis for every policymaking, especially concerning the collection development. Every decision taken by the library will always refer to Muhammadiyah's religious vision to create a sustainable UMY Library program and service. Following the ideological vision of the above institutions is the key to good library institutional governance. That is, managers have guidelines or organizational policies to carry out the mandate of the organization, which is, in this case, the UMY Library.

Besides, the interview illustrates an interactive contestation between agents and structures (Giddens 1984; Bourdieu 1990). Agencies are managers or librarians who are responsible for UMY Library management, whereas, the structure includes institutional rules and policies that refer to the vision of Muhammadiyahism. The direction of Muhammadiyah's religious vision is reflected in its missionary activities so that library managers are bound by institutional policies in the collection development of UMY Library. This means that every policy, both written and oral, must be accommodated or implemented comprehensively. On the other hand, librarians feel open that according to them the collection development should not be mocked by local ideological or primordial aspects. The needs of users are the key that guides the collection development. The data confirm the struggle between structures and agencies in developing collections in libraries. The professional openness of a librarian has limitations in dealing with a binding structure. However, as a professional, library managers have a professional nature, so various strategies are carried out to open access to users. In line with the comments obtained from the informant, SAFD, which is reinforced by the following informants, SUSB and LANT, can be seen in the following.

"... we realize that collection development is not all able to meet the needs of all so many users, but at least the collaborations carried out by UMY Library, especially those directly related to the collection can add collections that are not only allocated from the university library budget. However, every collaboration must be more careful, not to be repeated as already experienced by UMY Library through the dissolution of established collection service, such as the Iranian Corner ... (Interview on June 27, 2019)"

The caution conveyed by those informants is a strong indication of the existence of ideological contestations that must be understood by library actors. If not, then the problems of termination of cooperation will continue to occur so that the policy steps taken by the library are not strong. This shows that the issue of religious ideology is very important for library leadership, especially at UMY Library. Ideology has the power that is 
contestation in its implementation. The contestation not only works at the ideological level but also in the political economy that encourages every actor to be involved in a battle of interests. Such things can be seen in the results of interviews with the following informant, LAHS.

"... we worked in designing the development of this collection using various methods and approaches ... some publishers came to the library offering their catalogs and we chose according to the needs of our institution, both academically and in the lines of struggle of our institution ... including writers from UMY lecturers, we asked their books to be reviewed and discussed in front of students ... the authors hope that with book reviews their writings can be understood by many people, especially students ... whose end is known by the public and marketable. Besides that, we also immediately met with the leader of the university to report our collection development... (Interview was conducted on June 26, 2019)"

The last point of the interview was that the communication efforts of the library with UMY university leaders also paid off. Collection needs for library users can be brought easily by the library because of the strategic approach taken. So, the issue of the need for collection development budget is probably not a problem for UMY Library, because the needs for collections among users have been handled quickly. The library negotiation ability to obtain a budget at university also runs well. This shows a process of internal institutional political economy functioning properly, through the communication capabilities of the library leadership to achieve its budget from the institutional level.

The contestation is not only about ideology and economy, but also in terms of culture. This can be seen in the results of interviews conducted by Wijayanti (2018) as follows.

"... I like everything about art. I also have a drama community on campus. So, I brought an institution that I lead with art. It is my specialty, so if the embassy people think that the Amcor UMY has a Jam Session, there is an International Jazz Day, there are events, all of them are art, so maybe they are carried away by my style of art. That's what I call modify. Because I initiate, all imitate finally modified, so there was no plagiarism. There is the distinctiveness of each. That's what I hold ... (PU)"

The interview results above illustrate the existence of a struggle for cultural interests to elevate their respective cultural values, both Corner owner of America and host of the American Corner - a corner management place namely UMY. America as a corner owner feels that it is necessary to arrange all the program activities held by the Corner to be in line with the vision of the corner establishment to introduce American culture to the world community. On the other hand, the UMY Library represented by the Corner manager shows his identity as an actor who also has the freedom to decide which activities were the best for both parties, not just one of the parties who benefited. Therefore, various program innovations have been carried out by the manager to provide rights for both parties. These cultural programs affirm the existence of a contestation process because it is driven by the interests of each actor or stakeholder in filling library information, in the form of activities or physical collections, all of which lead to the formation of information for various groups. This is confirmed in the statement of the informant held by Wijayanti (2018) as follows. 
"... I want to counter, so there is a balance. This is all the issue from America. Surely the good side of America should be raised. But you may as a host say I want to pair this person actually against. That can't be ... They don't want things that might be contradictory or then bring down America itself ... because our mission, Amcor UMY is not only known in UMY. We want if people know we have Amcor so that it is the impact of soft marketing, the impact is that people know UMY right, people come to UMY. (PU)"

The statement above clearly shows the hidden importance of the commodification of audiences. Amcor's programs strive to introduce American culture as well as being used to introduce UMY to the program audiences. All programs are designed to be sold to audiences in a symbolic sense. That is, these programs generate added value for both parties, towards America as well as UMY. Both require recognition from the public to gain cultural benefits and the ends are in the form of economic capital. The cultural values created by the Amcor programs provide an opportunity for both to accumulate born capital into added value for the development of both parties in the global world community (Mosco 1996).

A variety of capitals were developed by the manager of Amcor UMY whose accumulation was in the form of added value in developing UMY Library collection. The process of capital accumulation by managers can be seen in Wijayanti (2018), which stated that related to the management of Amcor UMY, owners of capital have determined programs to create possible situations that facilitate capital accumulation above, first, the smooth running of America's programs, such as Session, International Jazz Day, and so on. Such programs will accommodate their interests through a cultural approach on the one hand. The library is allowed to present or perform a local culture, by involving local culture, and activists of local culture on the other side. This will direct the public mind among the society that American culture is a culture that provides a place for every culture and the point will be brought by the audience and the realization of added value for the Amcor owner. That is, public recognition of American culture as an egalitarian culture has been realized. Another added value, it turns out that students also are happier to work at Amcor to pursue scholarships, while improving their English and meeting points.

\section{Conclusion}

Collection development of UMY Library is found that the management of collection does not only occur through professional governance, which is driven by the needs of the public in general and openly, but also through the discourse of ideological contestation and commodification. Ideological contestation occurs in three formations, namely internal institutions, external institutions, and professional librarians, all of which are connected in a structure and agency link (Giddens 1984) or habitus (Bourdieu 1990). Internal institutions represented by the formation of the Muhammadiyah religious ideology oriented to the ideology of the Qur'an and the Sunnah, which are characterized as reformer institution encountering other religious ideologies, such as the movement of the Shiite groups represented by the Iranian Corner and the liberal movement represented by American Corner and others. The ideological interaction and contestation of these three parties face each other 
as a structure that influences each other in developing library collections. This form of contestation can be seen as the main form of ideological contestation in the collection development of UMY Library.

The second ideological interaction is the contestation between structure and agency. The structure is played by institutional elements, namely UMY Library as an institution that has rules or policies that are a guide for library actors. Actors are played by librarians, library managers, who are critical and professional. However, it is found that the professionalism of librarians was held hostage by the power of institutional ideology. However, librarians have various strategies to play this collection discourse at UMY Library. They conducted the selection and placement of collections, which were considered contrary to the religious vision of the Muhammadiyah organization into Islamic collections in general. This battle is not only based on the ideological discourse above, but also the infiltration of the commodification of institutions and audiences. Institutional commodification is used as a means to gather people in introducing parties, namely UMY Library and other external parties, such as Amcor and Iranian Corner. Meanwhile, the commodification of audiences is used as a means to ensure that people who have access to the library will build a cultural understanding of Amcor, UMY, and so on.]

\section{References}

Abdullah, Irwan. 2009. Konstruksi dan Reproduksi Kebudayaan. Yogyakarta: Pustaka Pelajar.
Althusser, Louis. 2014. On the Reproduction of Capitalism: Ideology and Ideological State Apparatuses. London: Verso.

Asyari, Suaidi. 2009. Nalar Politik NU \& Muhammadiyah. Yogyakarta: LKiS.

Barker, Chris. 2004. The Sage Dictionary of Cultural Studies. London: Sage Publication.

Barker, Chris. 2005. Cultural Studies Theory and Practice. New Delhi: Sage Publications.

Barthes, Roland. 1981. Elements of Semiology. New York: Hill and Wang.

Bourdieu, Pierre. 1986. Distinction: A Social Critique of the Judgement of Taste. New York: Routledge.

Bourdieu, Pierre. 1990. The Logic of Practice. California: Stanford University Press.

Bourdieu, Pierre. 1991. Language and Symbolic Power. Massachusetts: Harvard University Press.

Bourdieu, Pierre. 1998. Acts of Resistance: Against the Tyranny of the Market. New York: The New Press.

Buschman, John E. 2003. Dismantling the Public Sphere: Situating and Sustaining Librarianship in the Age of the New Public Philosophy. London: Libraries Unlimited.

Denzin, Norman K. and Yvonna S. Lincoln, eds. 1997. Handbook of Qualitative Research. London: Sage Publication. Pvt. Ltd.

Eagleton, Terry. 2006. Teori Sastra: Sebuah Pengantar Komprehensif.Yogyakarta: Jalasutra.

Evans, G. Edward. 2000. Developing Library and Information Center Collections. London: Libraries Unlimited.

Fatmawati, Endang, Wening Udasmoro, and Ratna Noviani. 2017. "Representation of Library Spaceas Pragmatic Space and 
Ideological Contestation." Libraria: Jurnal Ilmu Perpustakaan dan Informasi 6(1):1328.

Giddens, Anthony. 1984. The Constitution of Society. Malden: Polite Press.

Grenfell, Michael. 2010. Pierre Bourdieu: Key Concepts. Durham: Acumen.

Harker, Richard, Cheelen Mahar, and Chris Wilkes, eds. 2005. (Habitus X Modal) + Ranah = Praktik: Pengantar Paling Komprehensif kepada Pemikiran Pierre Bourdieu. Yogyakarta: Jalasutra.

IFLA. 2019. "About the Acquisition and Collection Development Section." IFLA.org. Retrieved (https://www.ifla.org/about-theacquisition-collection-developmentsection).

Johnson, Peggy. 2018. Fundamentals of Collection Development and Management. Chicago: ALA.

Kroeber, A. L. and C. Kluckhohn. 1952. Culture: A Critical Review of Concepts and Definitions. Cambridge: The Museum.

Lappegård, Trude, Eva Bernhardt, and Frances Goldscheider. 2017. "Introduction to the Special Collection on Finding Work-Life Balance: History, Determinants, and Consequences of New Bread-Winning Models in the Industrialized World." Demographic Research 37(26):853-866.

Laugu, Nurdin. 2015. Representasi Kuasa dalam Pengelolaan Perpustakaan: Studi Kasus pada Perpustakaan Perguruan Tinggi Islam di Yogyakarta. Yogyakarta: Gapernus Press.

Leckie, Gloria J. and John E. Buschman. 2009. Information Technology in Librarianship: New Critical Approaches. London: Libraries Unlimited.
Leckie, Gloria J., Lisa M. Given, and John E. Buschman. 2010. Critical Theory for Library and Information Science: Exploring the Social from Across the Disciplines. California: Libraries Unlimited.

Malagueño, Ricardo, Sudarshan Pillalamarri, Amaury José Rezende, and Marcelo Botelho da Costa Moraes. 2019. "The Effects of Length of Service and Ethical Ideologies on Moral Development and Behavioral Intentions." Journal of Applied Accounting Research ahead-of-p(ahead-ofprint).

Margolis, Eric and Stephen Laurence. 2007. Creations of the Mind: Theories of Artifacts and Their Representation. Oxford: Oxford University Press.

Margulies, Jared D. 2018. "The Conservation Ideological State Apparatus." Conservation and Society 16(2):181-92.

Mosco, Vincent. 1996. The Political Economy of Communication: Rethinking and Renewal. London: Sage Publications.

Mulkhan, Abdul Munir. 2010. Ahmad Dahlan: Jejak Pembaharuan Sosial dan Kemanusiaan. Jakarta: Penerbit Buku Kompas.

Pawley, Christine. 2017. "Missionaries of the Book' or 'Central Intelligence' Agents: Gender and Ideology in the Contest for Library Education in Twentieth-Century America." Libraries: Culture, History, and Society 1(1):72-96.

Smith, Kevin B., John R. Alford, John R. Hibbing, Nicholas G. Martin, and Peter K. Hatemi. 2017. "Intuitive Ethics and Political Orientations: Testing Moral Foundations as a Theory of Political Ideology." American Journal of Political Science 61(2):424-37. 
Storey, John. 1993. An Introductory Guide to Cultural Theory and Popular Culture. Hertfordshire: Harvester Wheatsheaf.

Sugiono. 2006. Metode Penelitian Kuantitatif, Kualitatif, dan R\& D. Bandung: Alfabeta.

Sutrisno, Mudji and Hendar Putranto. 2005. Teori-Teori Kebudayaan. Yogyakarta: Kanisius.

Vidal, Sergi and Johannes Huinink. 2019. "Introduction to the Special Collection on Spatial Mobility, Family Dynamics, and Gender Relations." Demographic Research 41(21):593-616.

Wijayanti. 2018. "Perpustakaan Sebagai Arena Kontestasi Kepentingan: Studi Kasus Pengelolaan American Corner di Universitas Islam Negeri Syarif Hidayatullah Jakarta dan Universitas Muhammadiyah Yogya- karta." Universitas Gadjah Mada, Yogyakarta.

Williams, Raymond. 1987. Marxism and Literature. Oxford: Oxford University Press.

Yu, Liangzhi. 2019. “Towards Structure-Agency Integrative Theories for Information Access Disparity." Journal of Documentation 75(3):458-77.

Yusniah, Yusniah. 2019. "Praktik Kuasa dan Kepemimpinan di Perpustakaan Universitas Muhammadiyah Yogyakarta." Nusantara Journal of Information and Library Studies 2(1):67-77.

Zerek, Bogdan Filip. 2014. The Preservation and Protection of Library Collection: A Practical Guide to Microbiological Controls. Amsterdam: Elsevier. 